\title{
SIMPANG TIGA ABADI, KABUPATEN OGAN KOMERING ILIR, PROVINSI SUMATERA SELATAN: JEJAK SUNGAI LAMA DI LAHAN BASAH
}

\author{
Simpang Tiga Abadi Komering Ilir Regency, South Sumatera \\ Province: Trances of the Old River Wetland
}

\author{
Muhammad Fadhlan Syuaib Intan \\ Pusat Penelitian Arkeologi Nasional \\ Jl. Raya Condet Pejaten, No. 4, Sudiang Raya Makassar, Indonesia \\ geobugis@yahoo.co.id
}

\begin{abstract}
Naskah diterima: 18/02/2019; direvisi: 28/03-09/05/2019; disetujui: 25/06/2019
Publikasi ejurnal: 30/06/2019
\end{abstract}

\begin{abstract}
The east coast of South Sumatra is a wetland area that contains many archaeological remains, one of which is the Simpang Tiga Abadi Site, Simpang Tiga Village, Tulung Selapan District, Ogan Komering Ilir Regency, South Sumatra Province. The problem associated with wetlands in the research area is how the past community reached the Simpang Tiga Abadi site to conduct social relations with the local community. The aim of the study was to determine the geological environmental conditions of the study area, the shape and pattern of old river flows in the Eternal Three Junction area, and the position of the old river towards the Lebong Hitam River or the Lumpur River. In addition to the geological conditions of this site, we also discussed the mapping of old river trails, including the flow patterns and relations between old rivers and rivers that are still flowing at this time. The method applied, is literature review, geological survey, and map analysis. The results of field observations prove that the site landscape includes a terrestrial morphological unit with a slope of 0-2\%, and the height of the sea level is 1-7 meters. Deranged flow pattern, periodic river, and adult-old river stage. The composition of this site is swamp sediment, quartz sandstone, and tuff, and lineament as a result of geological structures. The old river reconstruction turned out to flow together with the Lebong Hitam River and Lumpur River. The Simpang Tiga Abadi site is inhabited from the 9th century to the 18th century.
\end{abstract}

Keyword: Wetland archaeology, old river trail, Sumpang Tiga Abadi Site.

\begin{abstract}
Abstrak
Pesisir timur Sumatera Selatan merupakan daerah lahan basah yang banyak mengandung tinggalan kepurbakalaan, salah satunya adalah Situs Simpang Tiga Abadi, Desa Simpang Tiga, Kecamatan Tulung Selapan, Kabupaten Ogan Komering Ilir, Provinsi Sumatera Selatan. Masalah yang terkait dengan lahan basah di wilayah penelitian, adalah bagaimana masyarakat masa lalu mencapai Situs Simpang Tiga Abadi untuk melakukan hubungan sosial dengan masyarakat setempat. Tujuan penelitian untuk mengetahui kondisi lingkungan geologi wilayah penelitian, bentuk dan pola aliran sungai lama di wilayah Simpang Tiga Abadi, dan posisi sungai lama tersebut terhadap Sungai Lebong Hitam atau dengan Sungai Lumpur. Selain kondisi geologi situs ini, dibahas pula tentang pemetaan jejak sungai lama, mencakup pola aliran dan hubungan antara sungai lama dengan sungai-sungai yang masih mengalir saat ini. Metode yang diterapkan, adalah kajian pustaka, survei geologi, dan analisis peta. Hasil pengamatan lapangan membuktikan bahwa bentang alam situs termasuk satuan morfologi dataran dengan kemiringan 0-2\%, dan ketinggian dari permukaan air laut adalah 1-7 meter. Berpola aliran deranged, sungai periodis, serta berstadia sungai dewasa-tua. Batuan penyusun situs ini adalah endapan rawa, batupasir kuarsa, dan tufa, serta kelurusan sebagai hasil dari struktur geologi. Rekonstruksi sungai lama ternyata alirannya menyatu dengan Sungai Lebong Hitam dan Sungai Lumpur. Situs Simpang Tiga Abadi dihuni dari abad ke-9 hingga abad ke-18.
\end{abstract}

Kata Kunci: Arkeologi lahan basah, jejak sungai lama, Situs Sumpang Tiga Abadi. 


\section{PENDAHULUAN}

Pulau Sumatera terletak di bagian barat Kepulauan Nusantara, di sebelah utara berbatasan dengan Teluk Benggala, di timur dengan Selat Malaka, di selatan dengan Selat Sunda, dan di barat dengan Samudera Hindia. Di sebelah timur Pulau Sumatra, banyak dijumpai rawa yang dialiri oleh sungai-sungai besar, antara lain; Asahan (Sumatra Utara), Kampar, Siak dan Sungai Indragiri (Riau), Batang Hari (Sumatra Barat, Jambi), Ketahun (Bengkulu), Musi, Ogan, Lematang, Komering (Sumatra Selatan), dan Way Sekampung (Lampung) (Intan, 2015, pp. 11-33, 2017, pp. 1-14).

Secara fisiografi, pesisir timur Sumatera Selatan merupakan wilayah lahan basah, dengan ketinggian di bawah 5 meter dari atas permukaan laut, yang dikenal dengan kawasan lahan basah Teluk Cengal, yang mencakup daerah Tulung Selapan, Cengal, dan Pematang Panggang. Simpang Tiga Abadi, bagian dari lahan basah Tulung Selapan adalah wilayah permukiman transmigrasi yang dihuni sejak lima tahun terakhir (gambar 1). Di area permukiman transmigrasi, oleh pemerintah dibuat saluran primer (SP) yang disebut kanal, yang berfungsi sebagai sarana transportasi air.

Penelitian di Teluk Cegal dilakukan pada Tahun 1992, 2012 dan 2015 oleh tim Balai Arkeologi Sumatera Selatan. Pada akhir 2015 terjadi kebakaran lahan di Cengal yang berakibat terungkapnya tinggalan arkeologis di wilayah Desa Ulak Kedondong, Kecamatan Cengal, Kabupaten Ogan Komering Ilir. Penggalian liar dilakukan secara besar-besaran menemukan berbagai jenis artefak, sisa-sisa bangunan kayu dan kepingan-kepingan papan perahu kuna dalam satu area yang luas. Selanjutnya, pada awal 2016 oleh tim Balai Arkeologi Sumatera Selatan di lokasi ini, menjumpai kondisi situs yang telah rusak karena kebakaran dan aktivitas penggalian liar oleh sekelompok orang untuk mengambil artefak emas, keramik, manik-manik dan bahkan tiang-tiang kayu bangunan kuna yang

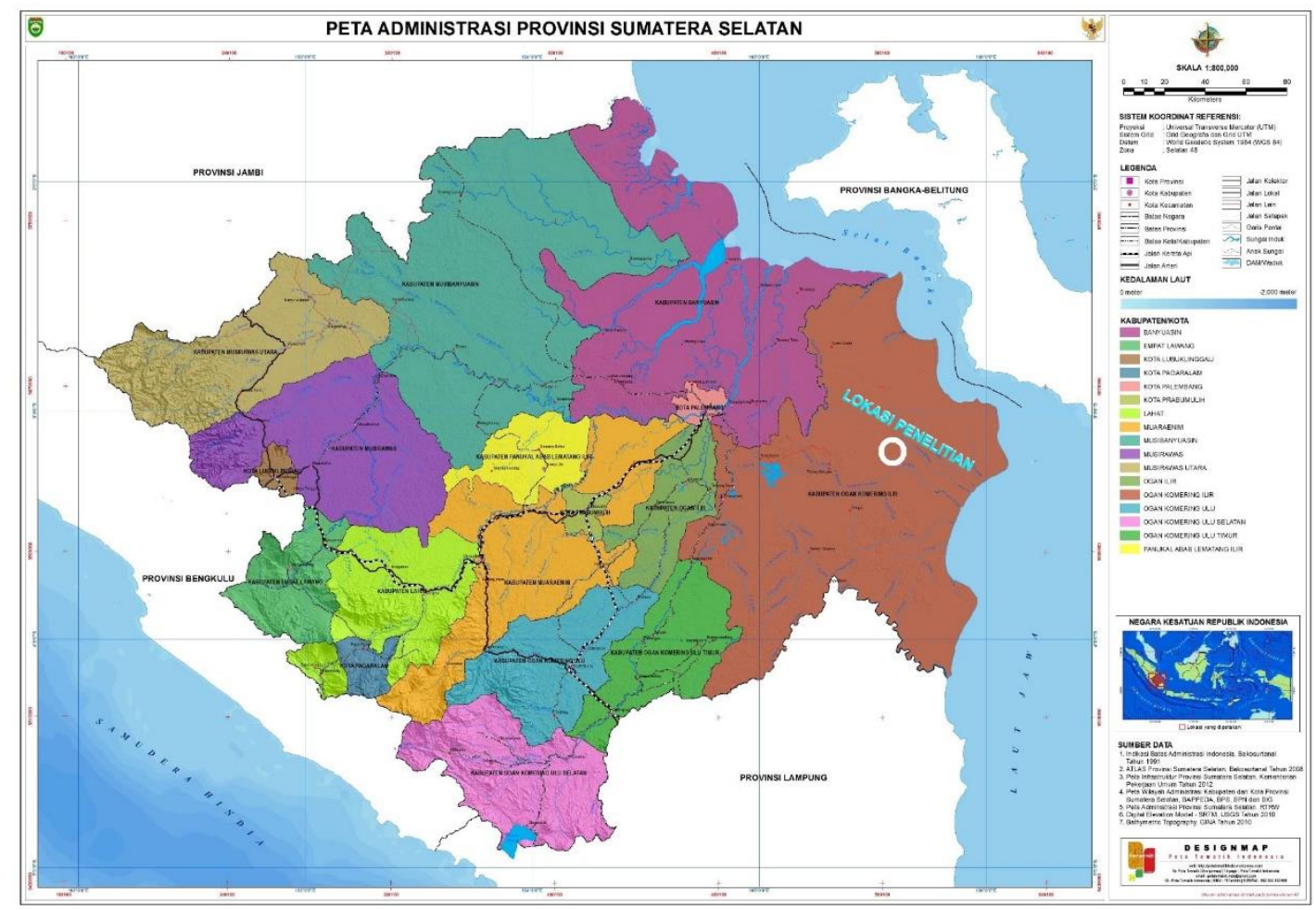

Gambar 1. Keletakan Sektor Simpang Tiga Abadi, Situs Tulung Selapan dalam peta wilayah Provinsi Sumatera Selatan (Sumber: Design Map, 2014 dengan modifikasi) 
dianggap bernilai ekonomi. Kawasan ini mencakup wilayah yang luas, di antara Sungai Langipi dan Sungai Ketupak, yang keduanya bertemu dengan Sungai Lumpur (Rangkuti, 2017).

Di wilayah Teluk Cengal, perahu kuna tradisi Asia Tenggara ditemukan pertama kali pada 1992 di Desa Tulung Selapan, Kecamatan Tulung Selapan. Sisasisa perahu yang ditemukan antara lain tali ijuk (arenga pinnata) sebagai pengikat papan perahu (sewn plank), pasak kayu dan papan-papan perahu (Wiyana, 2013, pp. 149-154). Temuan berikutnya pada tahun 2009 ketika seorang penduduk Desa Pasir, Kecamatan Cengal menemukan perahu kuna di dalam Sungai Pasir. Bangkai perahu kayu itu kemudian diangkat dalam kondisi yang relatif lengkap mulai dari bagian haluan sampai buritan. Tim Balai Arkeologi Sumatera Selatan meninjau temuan tersebut pada 2012. Dijumpai papan-papan perahu terserak di tanah dan sebagian papan-papan perahu dijadikan jerambah (jembatan) untuk menghubungkan rumah-rumah penduduk yang berupa rumah panggung dari kayu. Artefak-artefak yang ditemukan dalam perahu adalah fragmen-fragmen keramik, tembikar yang sebagian besar telah pecah, artefak-artefak kayu, tempurung kelapa, dan sisa perahu berupa bagian lunas, badan, buritan tempat kemudi (Wiyana, 2013, pp. 149-154).

Pada 2015 tim Balai Arkeologi Sumatera Selatan mendata temuan sekeping papan perahu di Desa Simpang Tiga Sakti, Kecamatan Tulung Selapan. Lokasi berada di sekitar aliran Sungai Bekasi bagian dari Sungai Lebunggajah. Panjang perahu di Sungai Bekasi sekitar 21-25 m. Sekitar 300 meter dari lokasi perahu ditemukan sisa-sisa tiang bangunan kayu dari batang nibung. Bagian perahu yang masih tersisa di lokasi adalah satu keping papan dengan lima tonjolan tambuku. Lubang-lubang pasak dan tali ijuk semuanya telah rusak, sebagian papan perahu ini terbakar akibat kebakaran lahan pada saat kemarau panjang. Selain di
Desa Simpang Tiga Sakti, juga dilakukan pengamatan di Desa Ulak Kedondong. Temuan perahu kuna berada di lokasi yang disebut Talang Sekuncit, Dusun 1 Desa Ulak Kedondong. Tim menemukan lima papan perahu kuna yang terbakar akibat kebakaran lahan gambut (Wiyana, Suranto, Sofian, \& Adhifani, 2015). Kawasan situs Ulak Kedondong merupakan bagian dari Daerah Aliran Sungai Lumpur di wilayah Kecamatan Cengal, Kabupaten OKI. Situssitus arkeologi terdapat pada aliran Sungai Langipi dan Sungai Ketupak (Rangkuti \& Wiyana, 2016).

Kecamatan Tulung Selapan memiliki lahan basah yang cukup luas, salah satu diantaranya berada di wilayah Desa Simpang Tiga. Lahan basah (wetland) mempunyai peranan penting bagi kehidupan manusia. Hal ini telah diakui dalam Konvensi Ramsar bahwa manusia mempunyai hubungan saling ketergantungan dengan lingkungan. Konvensi Ramsar adalah Convention on Wetlands of International Importance Especially as Waterfowl Habitat, yaitu perjanjian internasional untuk konservasi dan pemanfaatan lahan basah secara berkelanjutan, yang diadakan pada 2 Februari 1971 di Iran yang dihadiri 18 negara (Ramsar, 2013). Oleh Pemerintah Indonesia, konvensi ini diratifikasi pada tahun 1991 melalui Keputusan Presiden RI No. 48 tahun 1991, sehingga Indonesia memiliki tiga lokasi Ramsar yaitu Taman Nasional Merbak di Riau, Taman Nasional Danau Sentarong di Kalimantan Barat, dan Taman Nasional Wasur di Merauke Papua. Secara umum lahan basah dapat diartikan sebagai daerah peralihan antara sistem perairan dan sistem daratan. Lahan basah harus mempunyai paling sedikit salah satu ciri berikut: Paling sedikit secara periodik, lahan basah terutama mendukung hidrofita (tumbuhan air). Dengan demikian maka lahan basah merupakan ekosistem peralihan (ekoton) antara ekosistem perairan (aquatic) dan ekosistem daratan (terrestrial). 
Lahan basah (wetland) dalam arkeologi, oleh Rangkuti (2008) disebut dengan Arkeologi Lahan Basah (Wetland Archaeology) dan menyatakan bahwa pusat peradaban kuna juga muncul dari lahan basah, sehingga penelitian, pelestarian dan pemanfaatan situs-situs arkeologi di lahan basah sudah waktunya diprioritaskan. Selain itu dinyatakan bahwa, kehidupan manusia masa kini merupakan kelanjutan kehidupan manusia masa lalu, meskipun dengan kadar yang semakin meningkat. Menelusuri kehidupan masa lalu melalui benda dan situs-situs arkeologis mempunyai arti penting untuk memahami budaya masa lalu yang dapat dijadikan dasar dalam pembangunan jatidiri bangsa dan Negara (Rangkuti, 2008).

Lahan basah Situs Simpang Tiga Abadi menjadi sumber utama perekonomian, kebudayaan, ilmu pengetahuan maupun nilai rekreasi. Secara ekologis lahan basah berfungsi sebagai pengatur tata air dan sebagai habitat yang mendukung sifat-sifat flora dan fauna yang khas, terutama burung air.

Secara universal, kebutuhan manusia mencakup kebutuhan biologi (primer), kebutuhan sosial (sekunder), dan kebutuhan integratif (tertier). Ketiga kebutuhan itu merupakan perwujudan dari hakekat manusia sebagai makhluk pemikir dan berperasaan (Eriawati, 1997). Kebutuhankebutuhan manusia itu dicapai dengan cara memanfaatkan sumber-sumber daya yang ada dalam lingkungan, yang menjadi energi bagi kelangsungan hidupnya.

Lingkungan memang merupakan faktor yang penting bagi terciptanya suatu proses hubungan antara manusia dengan budayanya. Hubungan itu tidaklah sematamata terwujud sebagai hubungan ketergantungan manusia terhadap lingkungannya, tetapi juga terwujud sebagai suatu hubungan dimana manusia mempengaruhi dan merubah lingkungannya (Eriawati, 1997).
Segala kebutuhan hidup manusia tersebut dapat dipenuhi oleh keberadaan makanan pada lingkungan alam tempat mereka hidup. Daerah-daerah yang dipilih untuk dimukimi manusia adalah tempat yang dapat memberikan cukup persediaan bahan makanan dan air tawar, terutama di sekitar tempat-tempat yang sering dikunjungi atau dilalui hewan, seperti padang rumput, hutan kecil dekat sungai atau dekat rawa-rawa.

Lingkungan di wilayah Pesisir Timur Sumatera Bagian Selatan tempat ditemukannya situs yang memiliki karakter sebagai situs pemukiman, pada masa kini memperlihatkan morfologi lahan basah. Kondisi semacam itu dapat dikatakan bukanlah lingkungan yang nyaman sebagai tempat bermukim. Akan tetapi dari tinggalan arkeologis, baik dari segi jumlah maupun variasi, yang ditemukan di wilayah tersebut memperlihatkan bahwa wilayah tersebut dihuni oleh suatu kelompok dalam jangka waktu yang tidaklah sebentar, yang ditandai dengan adanya tiang-tiang bangunan. Jelas bahwa kondisi lingkungan masa lalu dengan sekarang tidaklah banyak berubah, namun memunculkan permasalahan, bagaimana masyarakat masa lalu mencapai Situs Simpang Tiga Abadi untuk melakukan hubungan sosial dengan masyarakat setempat.

Berdasarkan permasalahan tersebut, maka penelitian ini bertujuan untuk mengetahui 1) kondisi lingkungan geologi wilayah Simpang Tiga Abadi, 2) bentuk dan pola aliran sungai lama di wilayah Simpang Tiga Abadi, 3) posisi sungai lama tersebut, apakah ada hubungan aliran dengan Sungai Lebong Hitam atau dengan Sungai Lumpur dan, 4) menentukan letak situs di sungai lama yang ditemukan selama pemetaan. Tujuan pemetaan jejak sungai lama adalah mencari hubungan sungai-sungai lama dengan sungai-sungai yang hingga kini masih mengalir (Sungai Lebong Hitam dan atau Sungai Lumpur).

Lokasi penelitian difokuskan di wilayah Simpang Tiga Abadi yang 
termasuk wilayah administratif Dusun Simpang Tiga Abadi (dikenal dengan istilah SP5), Desa Simpang Tiga, Kecamatan Tulung Selapan, Kabupaten Ogan Komering Ilir (OKI), Provinsi Sumatra Selatan (gambar 1).

Secara geografis, lokasi penelitian terletak pada garis lintang $105^{\circ} 45^{\prime} 57,9^{\prime \prime}$ bujur timur dan $3^{\circ} 18^{\prime} 26,9^{\prime}$ lintang selatan, tercantum pada Peta Topografi Lembar SA48-15 (Toboali) Series T503, Edition 1AMS, Army Map Service Tahun 1944, berskala 1:250.000. Situs ini dapat dicapai dengan menggunakan kendaraan roda dua dan roda empat dari Kota Palembang, lalu dilanjutkan dengan menggunakan perahu bermotor dari Kota Tulung Selapan. Data yang digunakan dalam tulisan ini adalah hasil penelitian penulis bersama Tim Penelitian Balai Arkeologi Palembang Tahun 2018.

\section{METODE PENELITIAN}

Untuk mencapai tujuan penelitian yang diharapkan, maka diterapkan beberapa metode antara lain, kajian pustaka yang berkaitan dengan situs tersebut, melakukan pengamatan geologi (batuan, bentang alam, struktur geologi), melakukan pemetaan jejak sungai lama, dan keletakan sektor-sektor yang mengandung tinggalan arkeologi. Berdasarkan data-data lapangan, kemudian dilakukan interpretasi, baik dengan peta topografi maupun dengan peta geologi.

Pada penelitian ini dilakukan beberapa analisis, yaitu analisis petrologi (yang menyangkut batuan), dan analisis peta topografi (yang berkaitan dengan hubungan antar sungai). Dengan peta tersebut, akan diketahui jalur transportasi antara masyarakat setempat dengan masyarakat luar, dan lokasi-lokasi persinggahannya berdasarkan sektor-sektor yang mengandung temuan arkeologis, yang telah ditentukan keletakannya.

\section{HASIL DAN PEMBAHASAN}

\section{Geologi}

Morfologi atau bentuk bentang alam suatu daerah dipengaruhi oleh beberapa faktor yaitu, lithologi, struktur geologi, stadia daerah, dan tingkat erosi yang bekerja (Thornbury, 1964).

Secara umum bentang alam (morfologi) wilayah Simpang Tiga Abadi, memperlihatkan kondisi dataran rendah. Kondisi bentang alam seperti ini, apabila di klasifikasi berdasarkan Sistem Desaunettes

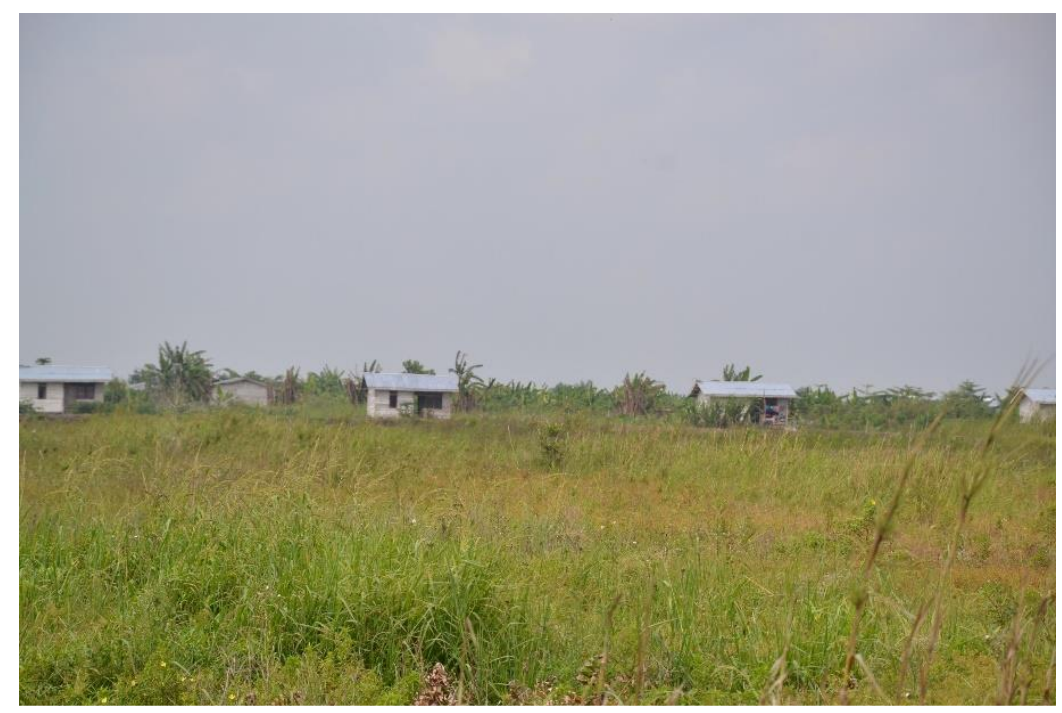

Gambar 2. Satuan morfologi dataran di Sektor Simpang Tiga Abadi, dengan bentuk permukaan yang sangat landai dan datar, mempunyai prosentase kemiringan lereng antara 0 - 2\% (Sumber: Dokomuntasi Balai Arkeologi Sumsel, 2018) 


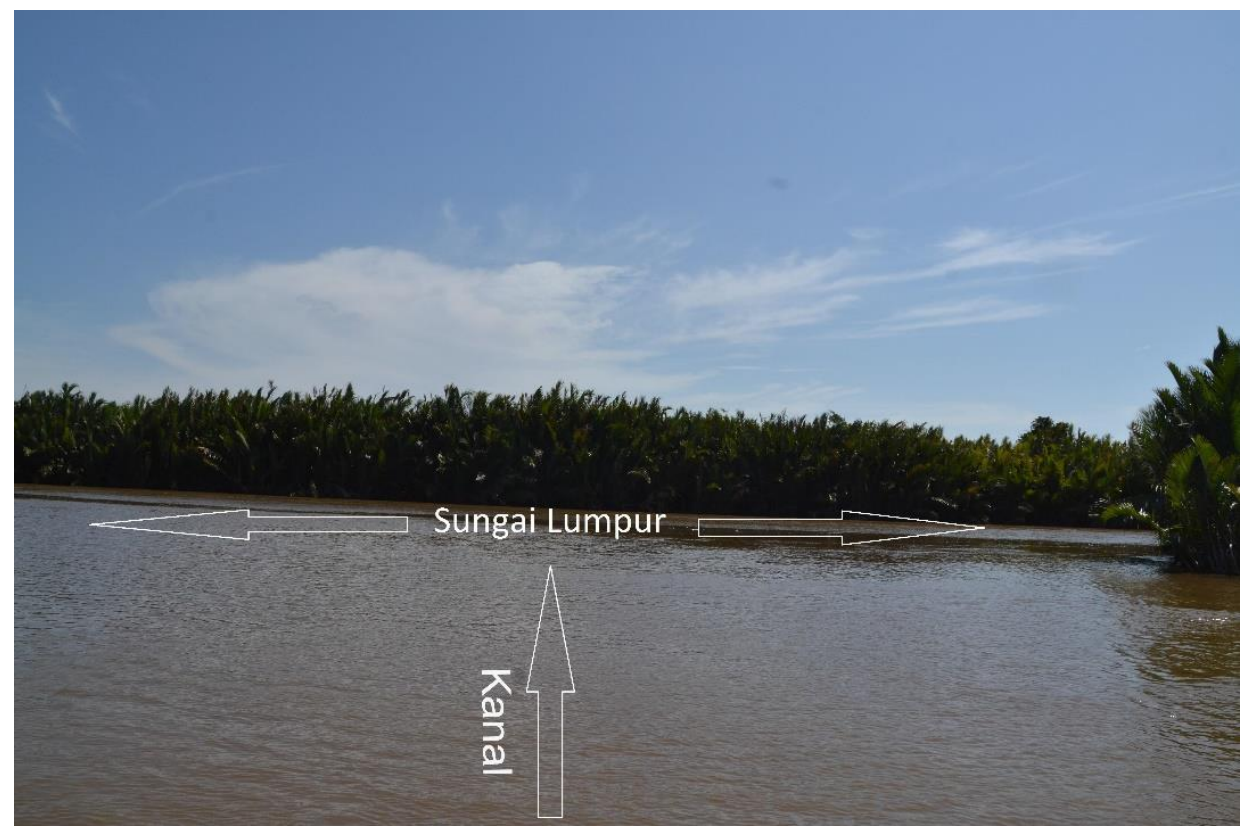

Gambar 3. Kanal di SP5 (Dusun Simpang Tiga Abadi), merupakan salah satu kanal yang ber muara di Sungai Lumpur, Kanal ini dibuat oleh pemerintah dengan fungsi sebagai jalur transportasi dan drainase pemukiman dan lahan pertanian (Sumber: Dokumentasi Balai Arkeologi Sumsel, 2018).

(Desaunettes, 1977; Todd, 1980), yaitu atas persentase kemiringan lereng dan beda tinggi relief suatu tempat, maka daerah penelitian termasuk dalam Satuan Morfologi Dataran.

Satuan Morfologi Dataran (gambar 2), berciri bentuk permukaan yang sangat landai dan datar, dengan persentase kemiringan lereng antara $0-2 \%$, bentuk lembah yang sangat lebar. Satuan morfologi ini menempati $100 \%$ dari wilayah penelitian. (Intan, 2015, pp. 11-33, 2017, pp. 1-14).

Sungai terbesar yang mengalir di Sektor Simpang Tiga Abadi dan sekitarnya adalah Sungai Lumpur dan Sungai Lebong Hitam.Sungai Lumpur berarah aliran dari barat daya ke timur laut berbelok ke arah tenggara dan bermuara di Laut Jawa,

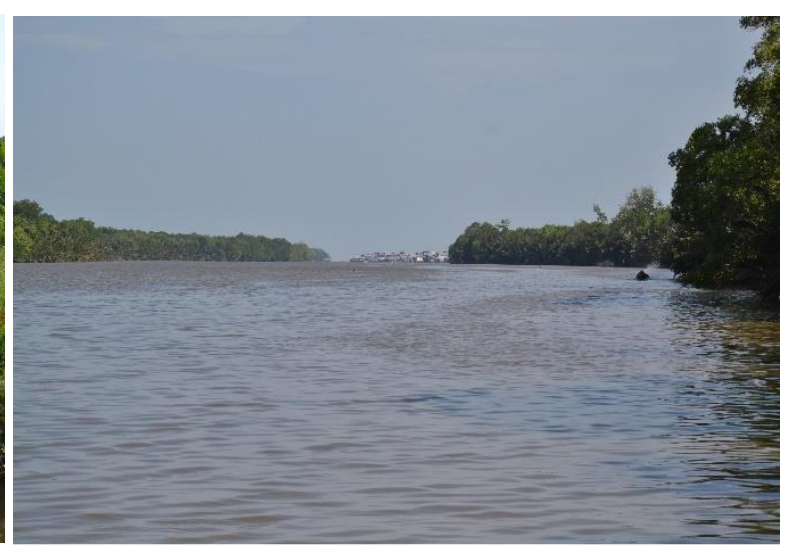

Gambar 5. Sungai Lumpur (salah satu sungai besar/induk) yang terletak di sebelah barat wilayah penelitian (Sumber: Dokumentasi Balai Arkeologi Sumsel, 2018).
Gambar 4. Kanal di SP5 (Dusun Simpang Tiga Abadi), merupakan salah satu kanal yang dibuat oleh pemerintah, berfungsi sebagai jalur transportasi dan drainase pemukiman dan lahan pertanian (Sumber:

Dokumentasi Balai Arkeologi Sumsel, 2018)

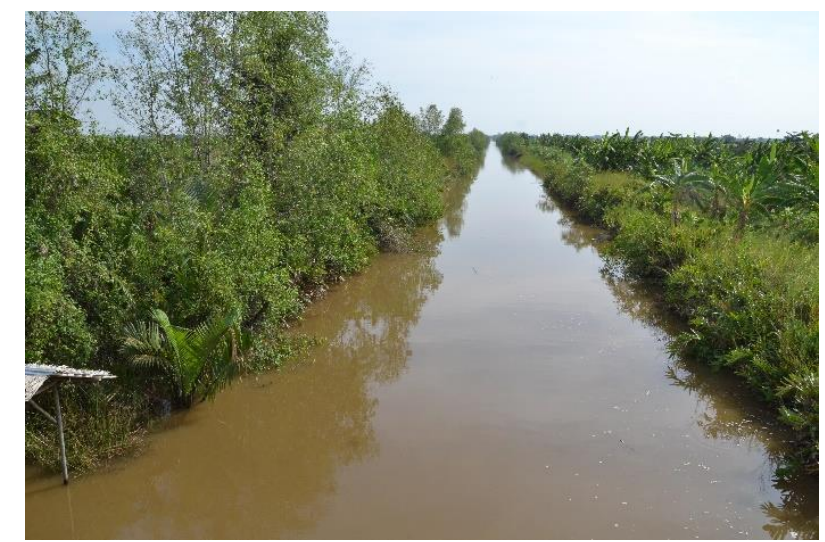


sedangkan Sungai Lebong Hitam berarah aliran dari barat laut ke arah tenggara dan bermuara di Laut Jawa. Sungai-sungai kecil lainnya adalah Sungai Langpipik, Sungai Ketupat, dan Sungai Pisang, serta beberapa anak sungai kecil lainnya.

Sungai Lumpur dan Sungai Lebong Hitam mempunyai arti penting bagi pembangunan pemukiman transmigran. Di area tersebut dibuat kanal-kanal selebar 20 meter yang berfungsi sebagai jalur transportasi dan drainase permukiman dan lahan pertanian (gambar 3).

Kanal-kanal itu oleh pemerintah masing-masing dinamai Saluran Primer (SP) dan setiap SP diberi nomor menurut urutan pembuatannya. Di wilayah penelitian terdapat kanal atau SP, misalnya SP1, SP2, SP3, SP4 dan SP5 (gambar 4).

Pola pengeringan permukaan (surface drainage pattern) sungai induk di lokasi penelitian menunjukkan arah umum dari barat laut ke tenggara dan bermuara di Laut Jawa. Sungai induk yang mengalir di wilayah penelitian adalah Sungai Lebong Hitam dan Sungai Lumpur (gambar 5).

Kelompok sungai tersebut termasuk pada sungai yang berstadia Sungai DewasaTua (old-mature river stadium). Keseluruhan sungai alam di wilayah penelitian, memberikan kenampakan Pola Pengeringan Deranged. Berdasarkan pada klasifikasi atas kuantitas air, sungai-sungai tersebut termasuk sungai periodis (Intan, 2015, pp. 11-33, 2017, pp. 1-14; Lobeck, 1939; Thornbury, 1964)

Dari pengamatan lapangan daerah penelitian pada umumnya merupakan daerah lahan basah. Secara umum wilayah Situs Simpang Tiga Abadi dapat dikelompokkan menjadi satuan batuan: 1) Endapan Rawa yang berumur Holosen; 2) Batuan Pasir Kuarsa yang berumur Holosen dan; 3) Batuan Tufa yang berumur Plistosen (Mangga, Sukardi, \& Sidaro, 1993) (gambar $6)$.

Hasil Interpretasi topografi, memperlihatkan bahwa di daerah penelitian

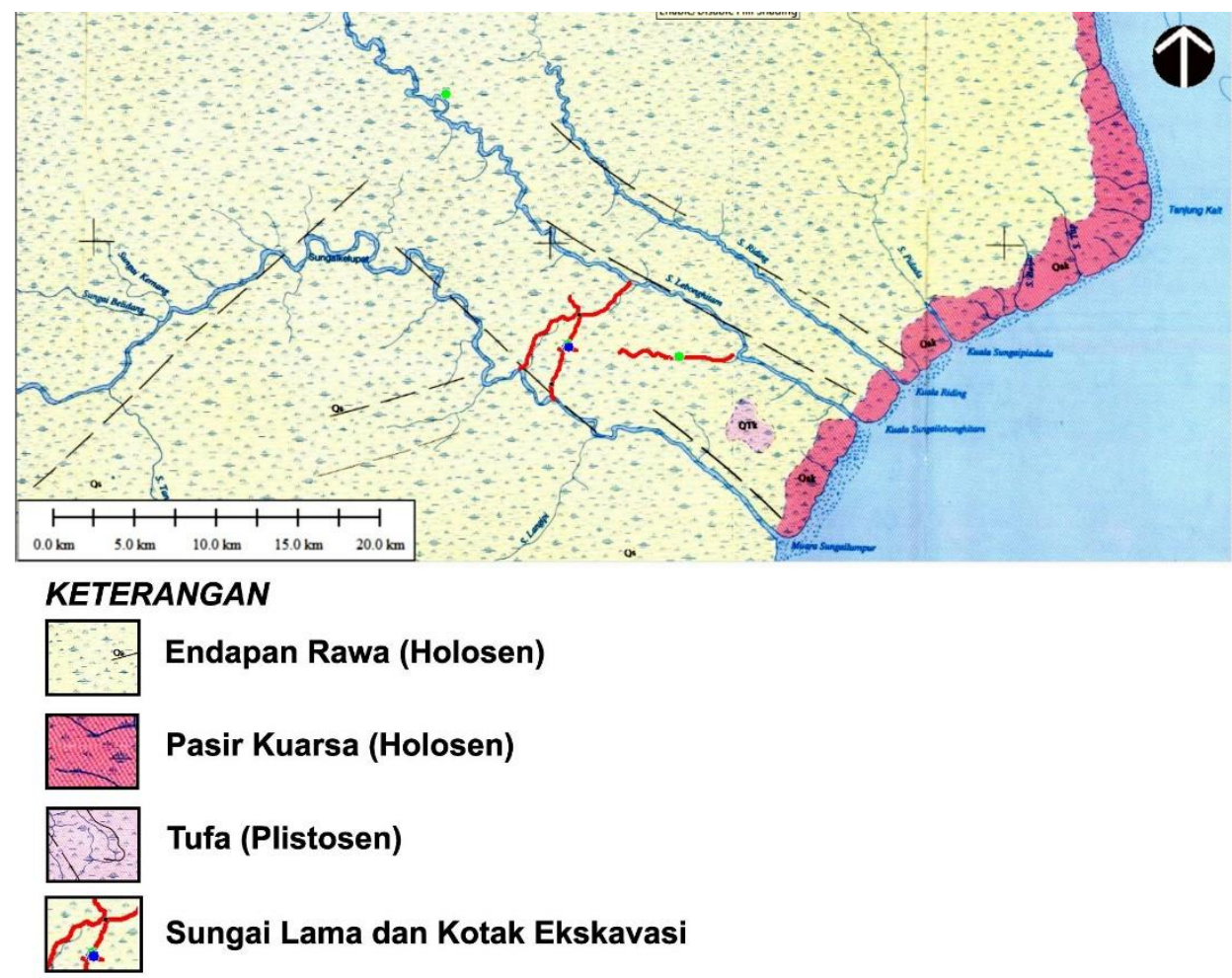

Gambar 6. Batuan penyusun wilayah penelitian (Sumber: Mangga et al., 1993, dengan modifikasi) 


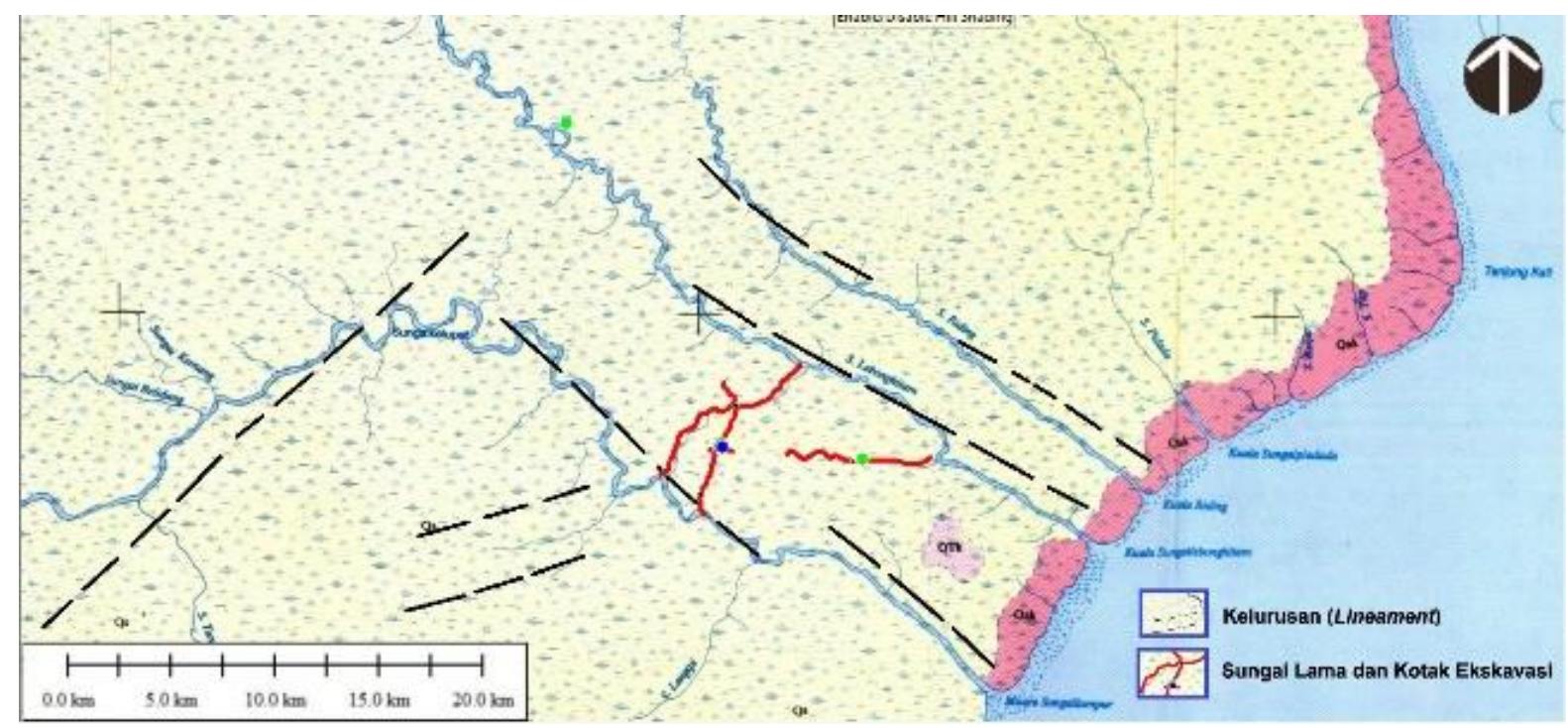

Gambar 7. Struktur geologi di wilayah penelitian berupa kelurusan (lineament) (Sumber: Mangga et. al., 1993, dengan modifikasi)

terdapat adanya kelurusan (lineament) yang digambarkan dalam bentuk garis putusputus, yang berarah barat laut - tenggara dan barat daya - timur laut. Sungai lama dan kotak ekskavasi terletak ditengah-tengah kelurusan (lineament) tersebut (gambar 7).

Kelurusan (lineaments) adalah cerminan morfologi yang teramati di permukaan bumi sebagai hasil dari aktivitas gaya geologi dari dalam bumi. Batasan kelurusan geologi disini adalah sebuah bentukan alamiah yang direpresentasikan oleh keunikan geomorfologi seperti; kelurusan punggungan, kelurusan lembah, kelurusan sungai, kelurusan yang disebabkan oleh sesar normal, sesar naik, maupun sesar mendatar. Kelurusan geologi bisa diasumsikan berupa unsur struktur geologi yang belum mengalami pergerakan (displacement), apabila sudah mengalami pergerakan, disebut dengan sesar (fault) (Biling, 1972).

\section{Survei dan Ekskavasi}

Kegiatan penelitian (Ekskavasi dan survei) di Sektor Simpang Tiga Abadi, dilakukan di Dusun Simpang Tiga Abadi, Desa Simpang Tiga, Kecamatan Tulung Selapan. Kegiatan ekskavasi dilakukan di
STA1 dengan membuka 14 kotak TP, yaitu TP1 hingga TP14. Tujuh kotak ekskavasi terletak di sungai lama, empat kotak ekskavasi terletak di pinggir sungai lama, dan tiga kotak ekskavasi terletak di luar sungai lama (Lampiran 1 dan 3). Temuan arkeologi dari kotak ekskvasi, berupa fragmen keramik, fragmen tembikar, tiang kayu, sisa hewan, sisa perahu, logam, batok kelapa, dan ijuk (Intan, 2018). Kegiatan survei dilaksanakan bersamaan dengan pemetaan jejak sungai lama, dan telah berhasil mendata 9 lokasi atau titik yang mengandung tinggalan arkeologi, yaitu Simpang Tiga Abadi-1 (STA-1) hingga Simpang Tiga Abadi-10 (STA-10) (Lampiran 2).

\section{Jejak Sungai Lama}

Pemetaan jejak sungai lama menggunakan peralatan Global Positioning System (Garmin GPSMAP76CSx) dan Kompas Geologi (Brunton 5006). Penentuan arah menggunakan kompas geologi, sedangkan penentuan titik koordinat menggunakan kode STA. Pemetaan sungai lama tahun 2018, di awali dari hasil Analisa Peta Topografi (APT) yang memberikan data bahwa ada beberapa sungai lama yang 
masih terdapat di wilayah Sektor Simpang Tiga Abadi dan sekitarnya kemungkinan besar dapat dihubungkan antar sungaisungai lama tersebut. Umumnya sungaisungai lama yang dipetakan mempunyai lebar 10 meter, dan lebar dataran banjirnya mencapai 5 - 10 meter, khusus di daerah muara, sungai lama ini mempunyai lebar mencapai 20 meter. Sungai-sungai lama di wilayah penelitian ditumbuhi jenis rerumputan yang menyukai lahan basah seperti rumput mendongan (Scirpus juncoides). Muara Sungai lama di Sektor Simpang Tiga Abadi dan sekitarnya yang terdekat adalah Sungai Lumpur dan Sungai Lebong Hitam yang bermuara di Laut Jawa.

Pemetaan sungai lama Tahun 2018 diawali di STA1 (kotak TP8) pada koordinat $03^{\circ} 18^{\prime} 23,8^{\prime \prime}$ LS - 10545'54,8” BT (GPS04) menuju ke arah utara melintasi jalan jalur 11 hingga pada koordinat $3^{\circ} 18^{\prime} 22,0^{\prime}$ ' LS - 105 45'56,2" BT (GPS-67) ditetapkan sebagai Sektor STA2. Jejak sungai lama bermeander ke arah utara dan pada koordinat $3^{\circ} 18^{\prime} 21,2$ " LS - 105 45'56,3” BT (GPS-82) ditetapkan sebagai Sektor STA-3. Selanjutnya jejak sungai lama berkelokkelok ke utara dan barat membentuk meander pada koordinat $3^{\circ} 17^{\prime} 22,8^{\prime}$ ' LS 105'46'18,3" BT (GPS-11), sungai lama bercabang ke arah barat, timur dan utara. Dari titik GPS-11 ke arah utara membentuk meander pada koordinat $3^{\circ} 17^{\prime} 05,4^{\prime \prime}$ LS $105^{\circ} 46^{\prime} 12,4$ " BT (GPS-13), selanjutnya berbelok ke arah barat laut dan pada koordinat 316'46,8' LS - 10546'00,9' BT (GPS-14) ditetapkan sebagai Sektor STA-8 (lampiran 4). Dari STA-8 jejak sungai lama tidak dapat dipetakan akibat lebatnya ilalang hingga ke Sungai Lebong Hitam yang berjarak 2,5 km.

Dari titik GPS-11 ke arah barat berkelok-kelok membentuk meander hingga pada koordinat $3^{\circ} 17^{\prime} 21,8^{\prime \prime}$ LS $105^{\circ} 46^{\prime} 12,1$ " BT (GPS-12), dan selanjutnya berbelok ke arah barat daya dan pada koordinat $3^{\circ} 17^{\prime} 37,2^{\prime \prime}$ LS - 105'45'23,5' BT (GPS-12A) sungai lama menyambung dengan anak Sungai Lumpur dan bermuara di Sungai Lumpur. Dari titik GPS-11 ke arah timur berkelok-kelok membentuk meander hingga ke arah timur laut dan pada koordinat $3^{\circ} 17^{\prime} 14,5^{\prime \prime}$ LS - 10547'06,2” BT (GPS11A) menyambung dengan Sungai Lumpur.

Pemetaan jejak sungai lama dilanjutkan dari GPS-54 (Pak Batur) di koordinat $3^{\circ} 18^{\prime} 44,6^{\prime \prime} \mathrm{LS}-105^{\circ} 49^{\prime} 38,5^{\prime \prime} \mathrm{BT}$ yang ditetapkan sebagai Sektor STA-6 (Lampiran 5). Jejak sungai lama di GPS-54 dilanjutkan ke arah timur dan pada koordinat 318'46,5" LS - 10549'38,9" BT (GPS54A), jejak sungai lama ini menyambung dengan anak Sungai Lebong hitam dan bermuara di Sungai Lebong Hitam. Pemetaan jejak sungai lama di GPS-54 dilanjutkan ke arah barat berbentuk meander ke arah utara berbelok ke arah selatan pada koordinat 318'45,2" LS - 105'49'32,9' BT (GPS-55), lurus ke arah barat daya hingga di koordinat 318'49,5" LS - 105'49'27,8” BT (GPS-56). Selanjutnya berbelok ke arah barat hingga di koordinat $3^{\circ} 18^{\prime} 48,8^{\prime \prime}$ LS 105'49'22,3" BT (GPS-51), lalu jejak sungai lama ini bermeander di koordinat $3^{\circ} 18$ ' $38,8^{\prime}$ ' LS - 105 49'56,8' BT (GPS-57), 3 ${ }^{\circ} 18^{\prime} 41,2^{\prime \prime}$ LS - 105'48'49,9" BT (GPS-58), 318'33,7" LS - 105'48'24,4” BT (GPS-59), berbelok ke arah barat daya pada koordinat $3^{\circ} 18^{\prime} 43,5^{\prime \prime} \mathrm{LS}-105^{\circ} 48^{\prime} 08,7^{\prime \prime}$ BT (GPS-60) hingga ke koordinat $3^{\circ} 18^{\prime} 33,2^{\prime \prime}$ LS $105^{\circ} 47^{\prime} 41,0$ " BT (GPS-61). dari titik GPS61 jejak sungai lama berbelok ke arah barat daya membentuk meander hingga pada koordinat $3^{\circ} 18^{\prime} 38,2^{\prime \prime} \mathrm{LS}-105^{\circ} 47^{\prime} 37,9^{\prime \prime}$ BT (GPS-63) dan selanjutnya pemetaan dihentikan karena jejak sungai lama ini tidak terdeteksi akibat pengolahan ladang yang sangat aktif.

Dari STA1 (kotak TP8) pada koordinat $03^{\circ} 18^{\prime} 23,8^{\prime \prime} \mathrm{LS}-105^{\circ} 45^{\prime} 54,8^{\prime}$ " BT (GPS-04) menuju ke arah barat daya hingga di koordinat $03^{\circ} 18^{\prime} 32,3$ " LS $105^{\circ} 45^{\circ} 48,4$ " BT (GPS-18) menjadi titik cabang ke arah barat dan ke arah selatan. Titik GPS-18 ke arah barat, jejak sungai lama terdeteksi di koordinat $03^{\circ} 18^{\prime} 32,2 \mathrm{LS}$ - 
$105^{\circ} 45^{\prime} 48,0$ ” BT (GPS-19), 03ำ18’32,4” LS - $105^{\circ} 45^{\circ} 47,3^{\prime \prime}$ BT (GPS-20), 03¹8'32,3” LS - $105^{\circ} 45^{\circ} 46,3 ”$ BT (GPS-21), $03^{\circ} 18$ '32,4” LS - 105'45‘41,2” BT (GPS22), $03^{\circ} 18^{\prime} 30,4^{\prime \prime}$ LS - $105^{\circ} 45^{\prime} 38,8^{\prime \prime}$ BT (GPS-23), 0318’30,0” LS - 105'45'38,3” BT (GPS-24) selanjutnya pemetaan dihentikan, karena pengerjaan ladang yang sangat aktif.

Titik GPS-18 ke arah barat, jejak sungai lama terdeteksi di koordinat $03^{\circ} 18^{\prime} 51,1 \mathrm{LS}-105^{\circ} 45^{\prime} 42,4$ ” BT (GPS-45) dan ditetapkan sebagai Sektor STA-9 (Gambar-11). Selanjutnya lurus ke arah selatan hingga di koordinat $03^{\circ} 19^{\prime} 35,8^{\prime \prime} \mathrm{LS}$ $105^{\circ} 45^{\prime} 26,9^{\prime}$ ' BT (GPS-37) dan ditetapkan sebagai Sektor STA-10 (lampiran 6). Jejak sungai lama lurus ke selatan hingga di koordinat $03^{\circ} 19^{\prime} 40,8$ “LS - $105^{\circ} 45^{\circ} 23,8^{\prime}$ ” BT (GPS-10A) merupakan titik pertemuan dengan sungai lama dari arah kiri. Pertemuan dua sungai lama dari titik GPS-
10A, lalu mengalir ke arah selatan dan pada koordinat $03^{\circ} 20^{\prime} 05,7$ "LS - $105^{\circ} 45^{\prime} 26,4^{\prime}$ " BT (GPS-99), jejak sungai lama menyatu dengan Sungai Lumpur.

Pemetaan jejak sungai lama dimulai lagi dari koordinat $03^{\circ} 20^{\circ} 05,7^{\prime \prime}$ LS $105^{\circ} 45^{\prime} 26,4^{\prime \prime}$ BT (GPS-81), ke arah barat, lalu berbelok ke arah utara, berbelok ke arah barat dan pada koordinat $03^{\circ} 18^{\prime} 26,6^{\prime \prime}$ LS $105^{\circ} 45^{\prime} 57,4$ ” BT (GPS-70) dan ditetapkan sebagai Sektor STA-5 (lampiran 7). Dari STA-5 jejak sungai lama berbelok ke utara dan berbelok ke arah barat hingga di koordinat $03^{\circ} 18^{\prime} 26,4$ "LS - $105^{\circ} 45^{\circ} 56,6$ " BT (GPS-69) dan ditetapkan sebagai Sektor STA-4 (lampiran 7). Selanjutnya jejak sungai lama ke arah barat laut dan lurus ke utara menyambung dengan sungai lama antara STA-1 dengan STA-2 di koordinat $03^{\circ} 18 ‘ 23,9^{\prime \prime} \mathrm{LS}-105^{\circ} 45^{\prime} 53,0^{\prime}$ ' BT (GPS66).

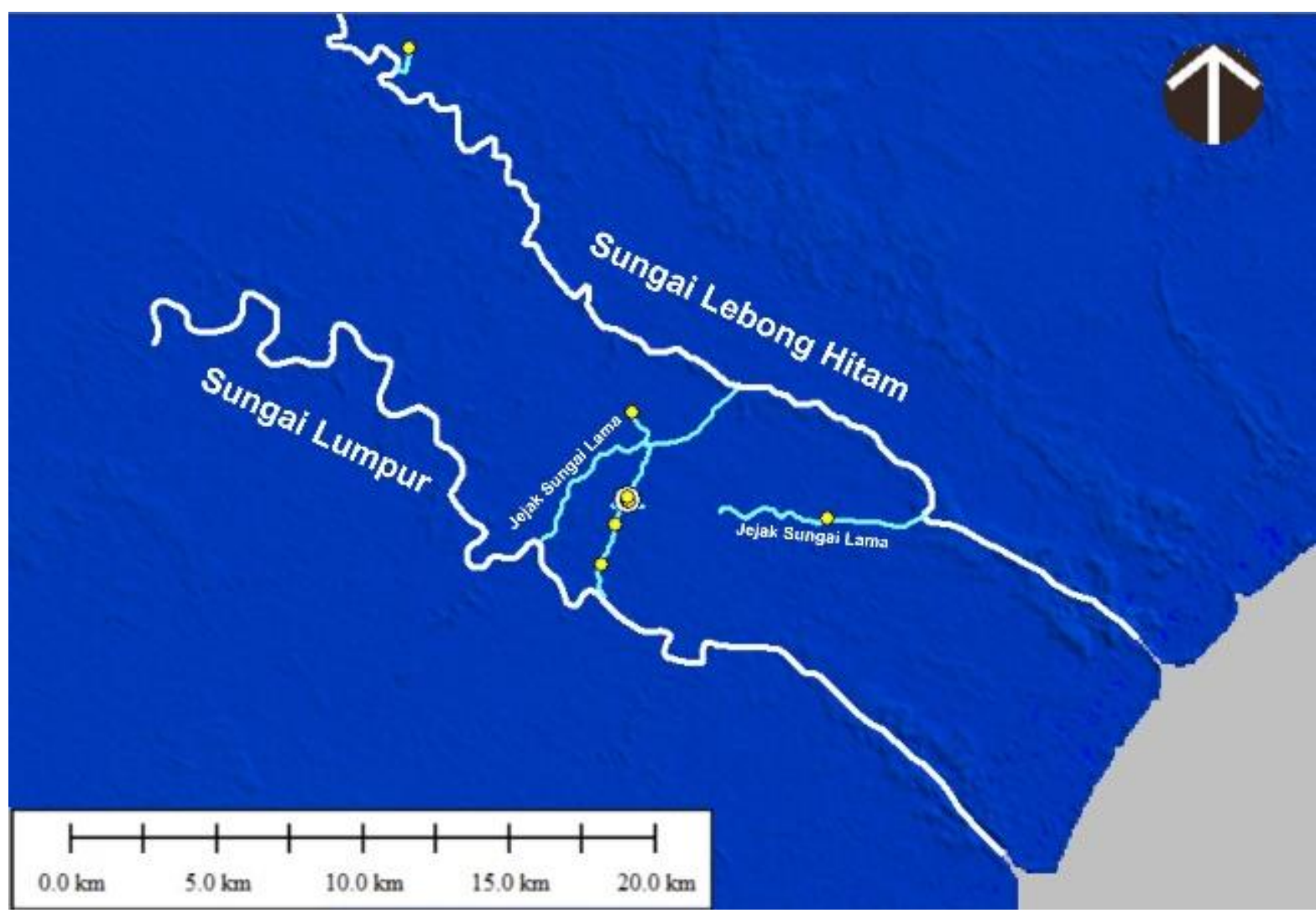

Gambar 8. Hasil pemetaan jejak di sungai lama yang terletak diantara Sungai Lebong Hitam dan Sungai Lumpur (Sumber: Intan, 2018; data topografi berdasarkan peta Jarvis et al.,tahun 2008) 


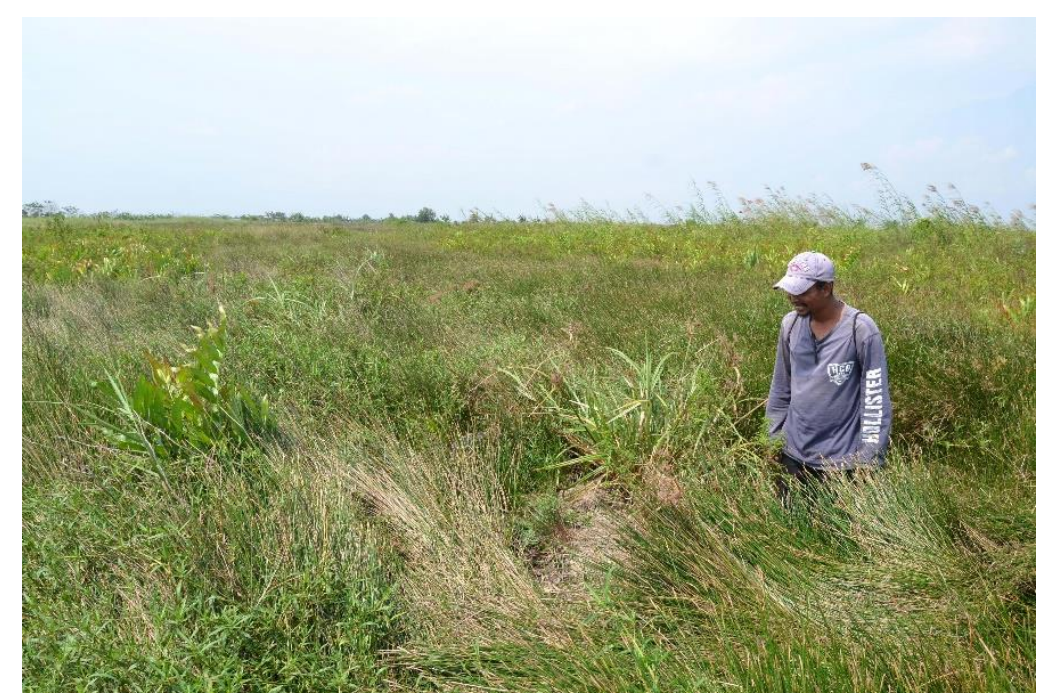

Gambar 9. Rumput mendongan (Scirpus juncoides), ciri khas tumbuhan di sungai lama (Sumber: Dokumentasi Balai Arkeologi Sumsel, 2018)

Sungai lama di Simpang Tiga Abadi, telah dapat direkonstruksi (gambar 8) dengan menggunakan Sektor STA-1 sebagai titik pusat, sebagai berikut:

- dari Sektor STA-1 sungai lama mengalir ke arah utara melewati Sektor STA-2 dan Sektor STA-3 dan pada koordinat $3^{\circ} 17^{\prime} 22,8^{\prime \prime}$ LS - 105'46'18,3” BT, sungai lama berbelok ke arah timur laut dan bermuara di Sungai Lebng Hitam.

- dari Sektor STA-1 sungai lama mengalir ke arah selatan melewati Sektor STA-9 dan Sektor STA-10 dan bermuara di Sungai Lumpur.

- dari koordinat $3^{\circ} 17^{\prime} 22,8^{\prime \prime}$ LS $105^{\circ} 46^{\prime} 18,3$ " BT, sungai lama mengalir ke arah barat lalu berbelok ke arah barat daya dan bermuara di Sungai Lumpur.

- $\quad$ sungai lama yang berarah barat-timur, mengalir ke timur melewati Sektor STA-6 dan bermuara di Sungai Lebong Hitam. Namun ke arah barat, sungai lama tersebut belum dapat dihubungkan dengan Sektor STA-1 sebagai titik pusat.

Sungai lama di Simpang Tiga Abadi mempunyai lebar 10 meter (dengan lebar dataran banjirnya mencapai 10 meter), dengan tumbuhan khas berupa rumput mendongan (Scirpus juncoides) (gambar 9).
Sektor STA-2 hingga Sektor STA-10 terletak di sisi kiri dan kanan dari sungaisungai lama.

Penentuan umur relatif Simpang Tiga Abadi dilakukan melalui temuan arkeologi berupa fragmen keramik, yaitu fragmen keramik Dinasti Tang dan Dinasti Qing. Berdasarkan hal tersebut, daerah ini telah dijadikan permukiman sejak abad IX Masehi hingga abad XVIII Masehi.

Sungai lama di Simpang Tiga Abadi, baik sungai induk maupun anak-anak sungainya berpola Deranged, dan saling menyambung hingga ke sungai sekarang (gambar 10) dan bermuara di laut, sehingga perahu menjadi satu-satunya alat transportasi untuk menjelajahi lahan basah di wilayah tersebut.

Hunian di Simpang Tiga Abadi ini merupakan pemukiman yang cukup padat yang berada di atas rawa, menempati rumahrumah bertiang (rumah panggung) yang didirikan di tepi sungai-sungai lama yang bermuara di Sungai Lebong Hitam dan Sungai Lumpur.

Sarana transportasi di sungai lama di Situs Simpang Tiga Abadi adalah perahu. Hasil survei menemukan sisa papan perahu dan kemudi di beberapa sektor, yaitu di Sektor-4 (ST-4) dan Sektor-7 (ST-7). 


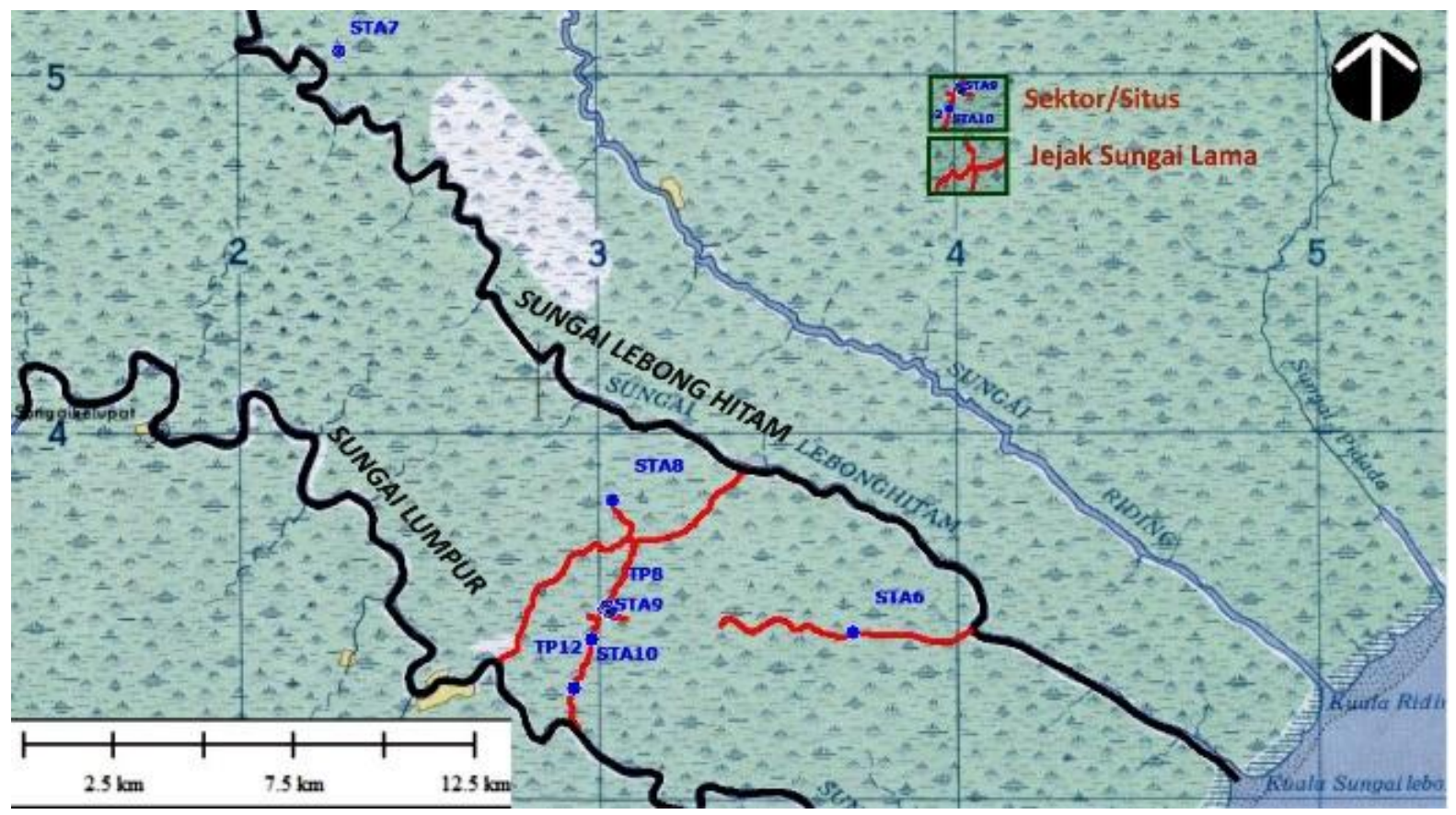

Gambar 10. Hasil pemetaan jejak di sungai lama di Simpang Tiga Abadi dalam peta topografi (Sumber: Army Map Service 1944 dengan modifikasi)

Temuan sisa perahu ini juga mencerminkan kondisi sosial masyarakat Situs Simpang. Temuan sisa perahu ini juga mencerminkan kondisi sosial masyarakat yang datang ke Situs Simpang Tiga Abadi di pesisir timur Sumatera Selatan masa lalu sebagai pedagang dan pelaut, dan Situs Simpang Tiga Abadi adalah pelabuhan penghubung sekaligus gudang bagi berbagai komoditas yang datang baik dari India, Tiongkok maupun dari Nusantara sendiri.

Pembukaan lahan basah untuk dimanfaatkan sebagai pemukiman transmigrasi, lahan pertanian dan perkebunan membawa dampak terhadap kehilangan sumber hayati, terjadi perubahan hidrologi dan iklim mikro. Dampak utama pada lahan basah adalah terjadinya penurunan kualitas lahan, seperti yang terlihat saat ini di Simpang Tiga Abadi, yaitu beberapa sungai lama tertutup atau tertimbun akibat pembuatan kanal atau jalur dan aktivitas penduduk. Namun dengan ditemukannya tinggalan arkeologis, baik dari segi jumlah maupun variasi di lokasi tersebut, memperlihatkan bahwa di Simpang Tiga Abadi telah dihuni oleh suatu kelompok dalam jangka waktu yang tidaklah sebentar, yang ditandai dengan adanya tiang-tiang bangunan berukuran cukup besar. Tiang-tiang bangunan berasal dari batang pohon Nibung (Oncosperma filamentosum) dan batang pohon Ulin (Eusideroxylon zwageri) yang diameternya 10-20 cm. Panjang rumah 15 meter, dengan jarak antar tiang adalah 2-2,5 meter, dengan melihat ukuran dapat dipastikan bahwa rumah tersebut termasuk kategori rumah yang besar, yang dapat dihuni hingga dua keluarga. Sebagai perbandingan, rumahrumah di lahan basah Simpang Tiga Abadi, hampir sama dengan rumah-rumah Suku Bugis yang saat ini mendiami daerah muara Sungai Lumpur.

\section{PENUTUP}

Jejak sungai lama di lahan basah Simpang Tiga Abadi, telah dapat direkonstruksi melalui pemetaan, berpola pengeringan permukaan (surface drainage pattern) dengan arah umum menyebar, berputar, mengikuti bentuk bentang lahan basah, berpola pengeringan Deranged, bermeander dengan tipe Sungai Dewasa-Tua 
(old-mature river stadium), dan bermuara di Laut Jawa. Umumnya sungai lama di wilayah penelitian mempunyai lebar 10 meter dengan dataran banjir mencapai 5-10 meter, sedangkan di daerah muara, mencapai lebar 20 meter, dengan vegetasi berupa rumput-rumputan yang dikenal dengan istilah rumput mendongan (Scirpus juncoides). Berdasarkan analisis petrologi, batuan penyusun wilayah penelitian adalah Endapan Rawa, Batupasir Kuarsa dan Tufa. Kelurusan (lineament) merupakan satusatunya struktur geologi yang melewati wilyah penelitian.

Kegiatan eksplorasi georkeologi dan pemetaan jejak sungai lama yang dilaksanakan di Simpang Tiga Abadi, Kecamatan Tulung Selapan, Kabupaten Ogan Komering Ilir (OKI), telah menemukan 10 titik/lokasi yang mengandung tinggalan arkeologi, yang terletak di sisi kiri dan kanan dari sungai lama.

Berdasarkan hasil pemetaan, maka sungai lama di Simpang Tiga Abadi dapat ditelusuri jejaknya yaitu, berarah dari timur laut - barat daya atau sebaliknya dari arah barat daya ke arah timur laut. Sungai lama yang berarah barat-timur, mengalir ke timur melewati Sektor STA-6 dan bermuara di Sungai Lebong Hitam, namun ke arah barat, sungai lama tersebut belum dapat dihubungkan dengan Sektor STA-1 sebagai titik pusat. Lahan basah Simpang Tiga Abadi dengan sungai lamanya, menggunakan perahu sebagai sarana utama untuk transportasi dan perdagangan. Perahuperahu yang menjelajah di sungai lama umumnya berukuran kecil, bila dibandingkan dengan perahu-perahu pedagang dari India, Tiongkok maupun dari Nusantara sendiri yang berlabuh di tepi Sungai Lebong Hitam dan atau di Sungai Lumpur. Temuan arkeologi baik dari segi jumlah maupun variasi, dan pertanggalan relatif, memperlihatkan wilayah ini dihuni oleh suatu kelompok dalam jangka waktu yang cukup panjang, yaitu dari abad ke-9 hingga abad ke-18.

\section{DAFTAR PUSTAKA}

Biling, M. P. (1972). Structural Geology. New Jersey: Prentice-Hall, Inc. Englewood Cliggs.

Desaunettes, J. R. (1977). Catalogue of landforms for Indonesia : examples of a physiographic approach to land evaluation for agricultural development [Unpublished]. Bogor: Trust Fund of the Government of Indonesia Food and Agriculture Organization.

Eriawati, Y. J. (1997). Penelitian Sumberdaya Alam (Lingkungan Vegetasi) Di Situs Kompleks Gua Wilayah Maros, Sulsel. Jakarta: LPA Bid. Arkeometri, Puslit Arkenas.

Intan, M. F. S. (2015). Eksplorasi Geoarkeologi Di Wilayah Air Sugihan, Sumatra Selatan. In Bambang Budi Utomo (Ed.), Kehidupan Purba di Lahan Gambut (pp. 11-33). Jakarta: Pusat Penelitian Arkeologi Nasional.

Intan, M. F. S. (2017). Banyu Biru: Jejak Sungai lama Di Lahan Basah. Siddhayatra, 22(1), 114. 
Intan, M. F. S. (2018). Lingkungan Geologi Sektor Simpang Tiga Abadi, Situs Tulung Selapan, Kabupaten Ogan Komering Ilir, Provinsi Sumatra Selatan.

Lobeck, A. K. (1939). Geomorphology, An Introduction To The Study of Landscape. New York and London: Mc Graw Hill Book Company Inc.

Mangga, A., Sukardi, \& Sidaro. (1993). Geologi Lembar Tulung Selapan, Sumatera. Puslitbang Geologi, Ditjen GSM, Deptamben.

Ramsar, C. S. (2013). The Ramsar Convention Manual: a guide to the Convention on Wetlands (Ramsar, Iran, 1971). Switzerland: Ramsar Convention Secretariat.

Rangkuti, N. (2008). Arkeologi Lahan Basah di Sumatera Bagian Selatan. In Sutikno (Ed.), Arkeologi Lahan Basah di Sumatera dan Kalimantan (pp. 1-21). Balai Arkeologi Palembang.

Rangkuti, N. (2017). Teluk Cengal: Lokasi Pelabuhan Sriwijaya? Berkala Arkeologi, 37(2), $125-140$.

Rangkuti, N., \& Wiyana, B. (2016). Hasil-Hasil Penelitian Arkeologi di Lahan Gambut Provinsi Sumatera Selatan. Palembang: Balai Arkeologi Palembang.

Thornbury, W. D. (1964). Principle of Geomorphology. New York and London: John Wiley and Sons, inc.

Todd, D. K. (1980). Groundwater Hydrology (Second Edi). New York: John Willey and Son's.

Wiyana, B. (2013). Temuan Perahu kuno di Sumatera Bagian Selatan. In Inajati Adrisijanti (Ed.), Perahu Nusantara (pp. 149-164). Yogyakarta: Kepel Press.

Wiyana, B., Suranto, Y., Sofian, H. O., \& Adhifani, W. R. (2015). Laporan Hasil Penelitian Arkeologi: Kronologi Situs di Kawasan Tulung Selapan Kabupaten Ogan Komering Ilir, Provinsi Sumatera Selatan. Palembang. 
Lampiran 1. Tabel kotak ekskavasi dan keletakannya

\begin{tabular}{|c|c|c|c|c|c|}
\hline No & Kotak & Koordinat & $\begin{array}{c}\text { Ketinggian } \\
\text { (mdpl) }\end{array}$ & Lahan & Keletakan \\
\hline 1 & TP1 & $\begin{array}{l}03^{\circ} 18^{\prime} 27,0^{\prime \prime} \mathrm{LS} \\
105^{\circ} 45^{\prime} 57,8^{\prime \prime} \mathrm{BT}\end{array}$ & 4,28 & Komaruddin & Pinggir Sungai lama \\
\hline 2 & TP2 & $\begin{array}{l}03^{\circ} 18^{\prime} 27,1 \text { " LS } \\
105^{\circ} 45^{\prime} 57,8^{\prime \prime} \mathrm{BT}\end{array}$ & 4,27 & Komaruddin & Pinggir Sungai lama \\
\hline 3 & TP3 & $\begin{array}{l}03^{\circ} 18^{\prime} 24,8^{\prime \prime} \mathrm{LS} \\
105^{\circ} 45^{\prime} 54,5^{\prime \prime} \mathrm{BT}\end{array}$ & 4,82 & Margono1 & Luar Sungai Lama \\
\hline 4 & TP4 & $\begin{array}{l}03^{\circ} 18^{\prime} 24,9^{\prime \prime} \mathrm{LS} \\
105^{\circ} 45^{\prime} 54,5^{\prime \prime} \mathrm{BT}\end{array}$ & 4,83 & Margono1 & Luar Sungai Lama \\
\hline 5 & TP5 & $\begin{array}{l}03^{\circ} 18^{\prime} 24,3^{\prime \prime} \mathrm{LS} \\
105^{\circ} 45^{\prime} 54,9^{\prime \prime} \mathrm{BT}\end{array}$ & 4,69 & Margono1 & Sungai Lama \\
\hline 6 & TP6 & $\begin{array}{l}03^{\circ} 18^{\prime} 24,1 \text { ' LS } \\
105^{\circ} 45^{\prime} 54,8^{\prime \prime} \text { BT }\end{array}$ & 4,72 & Margono1 & Sungai Lama \\
\hline 7 & TP7 & $\begin{array}{l}03^{\circ} 18^{\prime} 24,1 \text { " LS } \\
105^{\circ} 45^{\prime} 55,1^{\prime \prime} \mathrm{BT}\end{array}$ & 4,62 & Margono1 & Sungai Lama \\
\hline 8 & TP8 & $\begin{array}{l}03^{\circ} 18^{\prime} 24,1 \text { " LS } \\
105^{\circ} 45^{\prime} 55,3^{\prime \prime} \mathrm{BT}\end{array}$ & 4,57 & Margono1 & Sungai Lama \\
\hline 9 & TP9 & $\begin{array}{l}03^{\circ} 18^{\prime} 23,8^{\prime \prime} \mathrm{LS} \\
105^{\circ} 45^{\prime} 54,8^{\prime \prime} \mathrm{BT}\end{array}$ & 4,76 & Sophia & Pinggir Sungai lama \\
\hline 10 & TP10 & $\begin{array}{l}03^{\circ} 18^{\prime} 23,8^{\prime \prime} \mathrm{LS} \\
105^{\circ} 45^{\prime} 54,7^{\prime \prime} \mathrm{BT}\end{array}$ & 4,79 & Sophia & Pinggir Sungai lama \\
\hline 11 & TP11 & $\begin{array}{l}03^{\circ} 18^{\prime} 26,1 \text { " LS } \\
105^{\circ} 45^{\prime} 56,4^{\prime \prime} \mathrm{BT}\end{array}$ & 4,18 & Margono2 & Sungai Lama \\
\hline 12 & TP12 & $\begin{array}{l}03^{\circ} 18^{\prime} 25,7^{\prime \prime} \mathrm{LS} \\
105^{\circ} 45^{\prime} 56,1^{\prime \prime} \mathrm{BT}\end{array}$ & 4,28 & Margono2 & Sungai Lama \\
\hline 13 & TP13 & $\begin{array}{l}03^{\circ} 18^{\prime} 25,4^{\prime \prime} \mathrm{LS} \\
105^{\circ} 45^{\prime} 56,3^{\prime \prime} \mathrm{BT}\end{array}$ & 4,24 & Margono2 & Sungai Lama \\
\hline 14 & TP14 & $\begin{array}{l}03^{\circ} 18^{\prime} 26,1^{\prime \prime} \mathrm{LS} \\
105^{\circ} 45^{\prime} 55,9^{\prime \prime} \mathrm{BT}\end{array}$ & 4,38 & Margono2 & Luar Sungai Lama \\
\hline
\end{tabular}

Sumber: Intan, 2018 
Lampiran 2. Tabel keletakan Geografis Sektor-Sektor Simpang Tiga Abadi, Kec. Tulung Selapan, Kab. Ogan Komering Ilir (OKI)

\begin{tabular}{|c|c|c|c|c|c|}
\hline NO & SEKTOR & $\begin{array}{l}\text { LINTANG } \\
\text { SELATAN }\end{array}$ & $\begin{array}{l}\text { BUJUR } \\
\text { TIMUR }\end{array}$ & $\begin{array}{l}\text { KETINGGIAN } \\
\text { MDPL }\end{array}$ & TEMUAN \\
\hline 1 & STA-2 & $3^{\circ} 18^{\prime} 22,0^{\prime \prime}$ & $105^{\circ} 45^{\prime} 56,2^{\prime \prime}$ & 4,76 & $\begin{array}{ll}\text { tulang paha } & \text { (humerus), } \\
\text { fragmen } & \text { tembikar, fragmen } \\
\text { keramik } & \end{array}$ \\
\hline 2 & STA-3 & $3^{\circ} 18^{\prime} 21,2^{\prime \prime}$ & $105^{\circ} 45^{\prime} 56,3^{\prime \prime}$ & 4,94 & $\begin{array}{l}\text { fragmen tembikar, dan } \\
\text { fragmen keramik }\end{array}$ \\
\hline 3 & STA-4 & $3^{\circ} 18^{\prime} 26,4^{\prime \prime}$ & $105^{\circ} 45^{\prime} 56,8^{\prime \prime}$ & 4,15 & $\begin{array}{l}\text { sisa perahu, fragmen tembikar } \\
\text { dan fragmen keramik }\end{array}$ \\
\hline 4 & STA-5 & $3^{\circ} 18^{\prime} 26,6^{\prime \prime}$ & $105^{\circ} 45^{\prime} 57,4^{\prime \prime}$ & 4,13 & $\begin{array}{l}\text { tiang-tiang kayu (batang } \\
\text { pohon) yang pernah } \\
\text { dimanfaatkan sebagai tiang } \\
\text { bangunan }\end{array}$ \\
\hline 5 & STA-6 & $3^{\circ} 18^{\prime} 44,6^{\prime \prime}$ & $105^{\circ} 49^{\prime} 38,5^{\prime \prime}$ & 6,63 & $\begin{array}{l}\text { fragmen keramik dan botol } \\
\text { Belanda }\end{array}$ \\
\hline 6 & STA-7 & $2^{\circ} 18^{\prime} 26,9^{\prime \prime}$ & $105^{\circ} 45^{\prime} 26,9^{\prime \prime}$ & 4,76 & $\begin{array}{l}\text { sisa perahu, kemudi, fragmen } \\
\text { tembikar, fragmen keramik, } \\
\text { dan fragmen tulang }\end{array}$ \\
\hline 7 & STA-8 & $3^{\circ} 16^{\prime} 48,8^{\prime \prime}$ & $105^{\circ} 46^{\prime} 00,9^{\prime \prime}$ & 5,13 & $\begin{array}{l}\text { empat tiang nibung, beberapa } \\
\text { tiang nibung lainnya sudah } \\
\text { tercabut bersama fragmen } \\
\text { tembikar akibat pembuatan } \\
\text { saluran tersebut }\end{array}$ \\
\hline 8 & STA-9 & $3^{\circ} 18^{\prime} 51,1^{\prime \prime}$ & $105^{\circ} 45^{\prime} 42,4^{\prime \prime}$ & 5,87 & $\begin{array}{l}\text { tiang-tiang nibung (ujungnya } \\
\text { runcing) baik yang masih } \\
\text { tertanam di saluran sekunder } \\
\text { maupun yang telah tercabut } \\
\text { dari sungai lama }\end{array}$ \\
\hline 9 & STA-10 & $3^{\circ} 19^{\prime} 35,8^{\prime \prime}$ & $105^{\circ} 45^{\prime} 26,9^{\prime \prime}$ & 4,20 & $\begin{array}{l}\text { tiang-tiang nibung (ujungnya } \\
\text { runcing) yang telah tercabut } \\
\text { dari sungai lama, dan fragmen } \\
\text { tembikar }\end{array}$ \\
\hline
\end{tabular}

Sumber: Intan, 2018 
Lampiran 3. Gambar peta keletakan TP1 hingga TP14 di sungai lama yang berada diantara Sungai Lebong Hitam dan Sungai Lumpur (Sumber: Intan 2018)

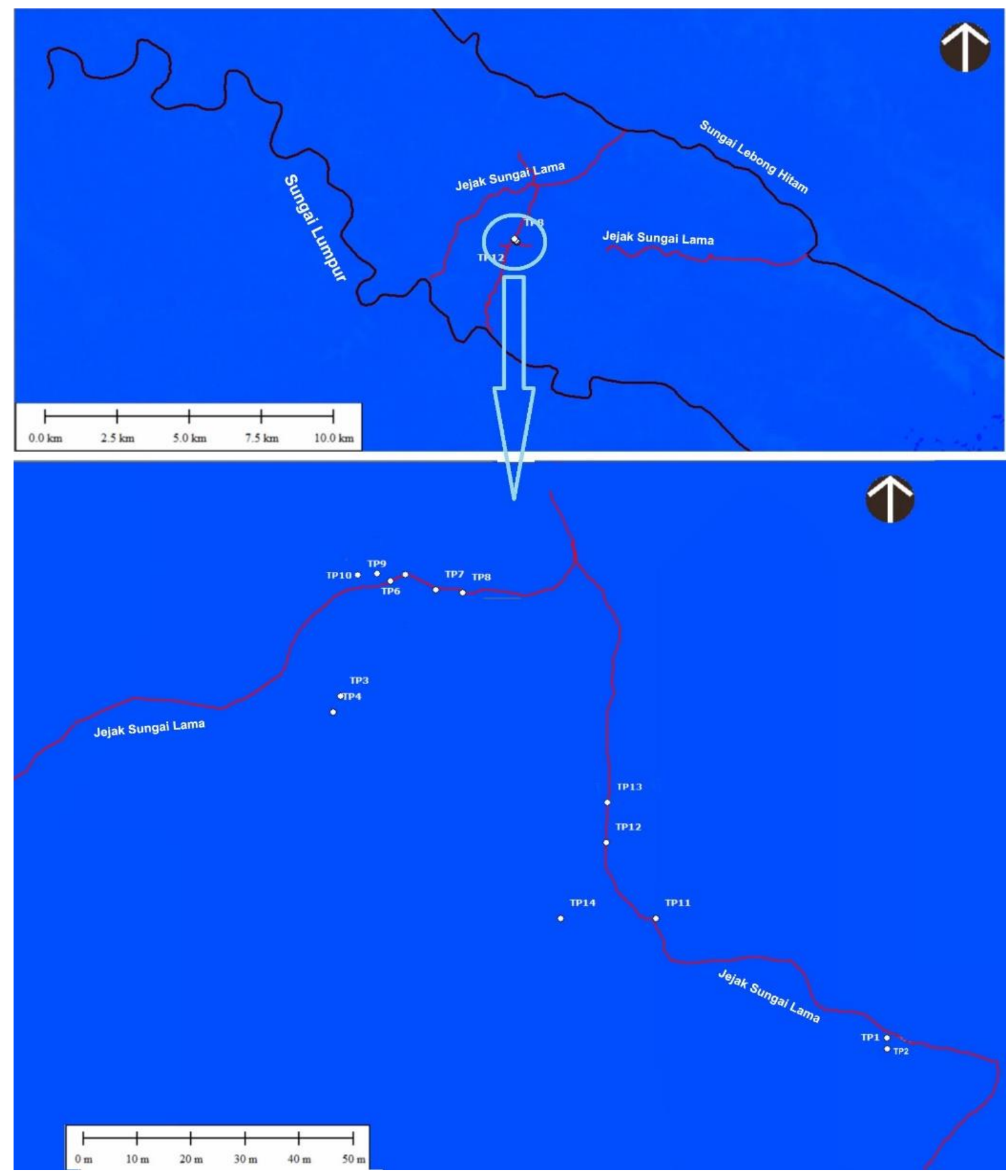

Jurnal Walennae, Vol. 17, No. 1, Juni 2019: Hal. 37-56|53 
Lampiran 4. Gambar peta Keletakan STA8 di sungai lama (Sumber: Intan 2018)

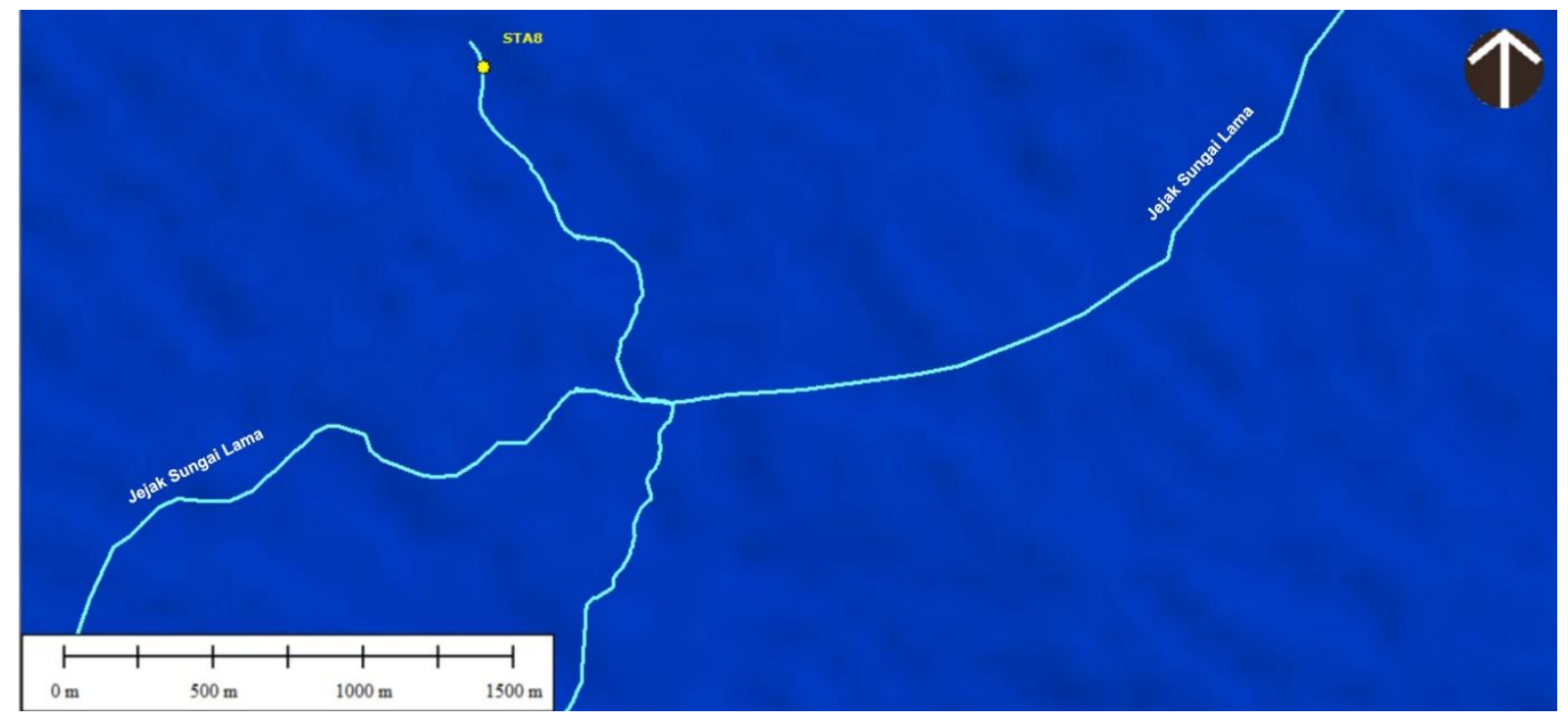


Lampiran 5. Gambar peta keletakan STA6 di sungai lama (Sumber: Intan 2018)

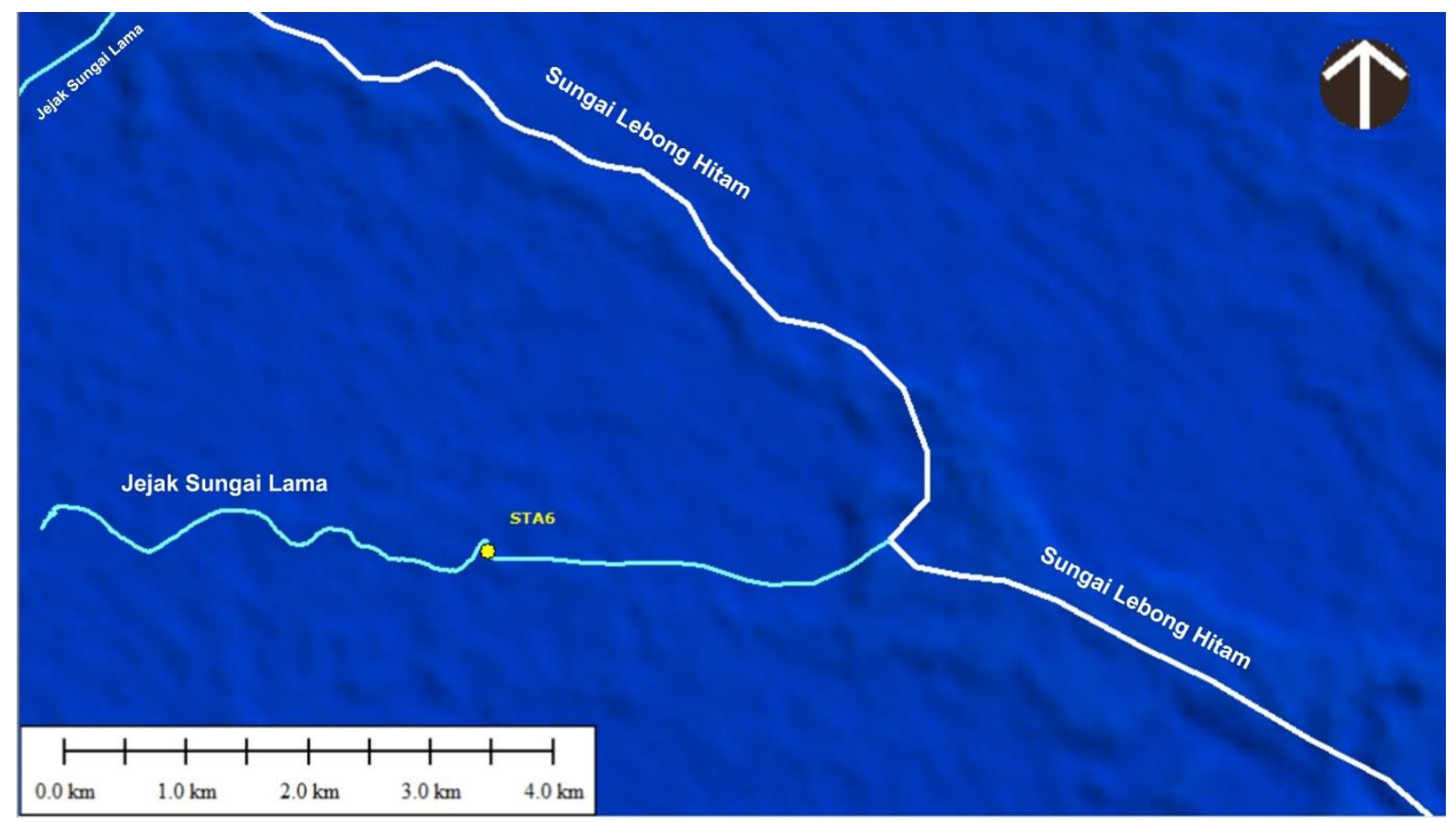

Jurnal Walennae, Vol. 17, No. 1, Juni 2019: Hal. 37-56|55 
Lampiran 6. Gambar peta keletakan STA9 dan STA10 di sungai lama (Sumber: Intan 2018)

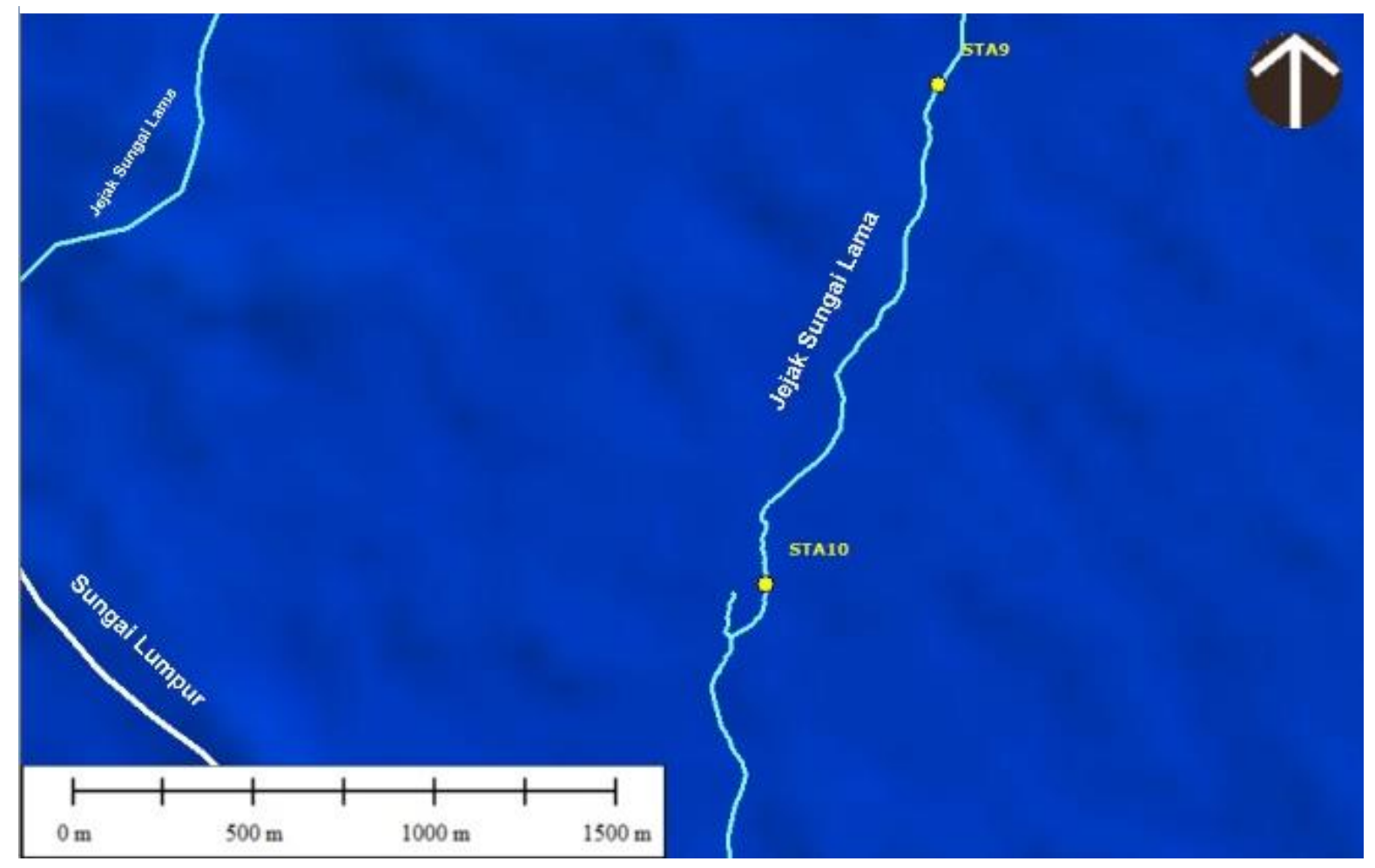

